DOI: https://doi.org/10.32836/2521-666X/2019-1-63-15

УДК 330.338 .1

\author{
Ecce O.I. \\ асистент кафедри підприємництва \\ та економіки підприємств, \\ Університет митної справи та фрінансів \\ Yesse Oksana \\ University Customs and Finance
}

\begin{abstract}
АНАЛІЗ РОЗВИТКУ МАЛОГО ПІДПРИЕМНИЦТВА В ДНІПРОПЕТРОВСЬКІЙ ОБЛАСТІ
\end{abstract}

\title{
ANALYSIS OF THE DEVELOPMENT OF SMALL BUSINESS IN THE DNIPROPETROVSK REGION
}

Статтю присвячено дослідженню малого підприємнищтва в Дніпропетровській області порівняно з показниками по Україні у цілому. Надано характеристику діяльності суб 'єктів господарювання в Україні та Дніпропетровській області з 2013 до 2017 р. за показниками кількості підприємств, кількості зайнятих прачівників та обсягами реалізованої продукиї з виділенням діяльності малих підприємств та оцінкою їхньої частки в загальній структурі. Визначено, щзо в Дніпропетровській області малий бізнес виконує соціальну функиію, тобто забезпечує більшу кількість населення робочими місиями. Розглянуто характеристику діяльності фізичних осіб - підприємиів за основними показниками. Окреслено проблеми малого підприємнищтва, які сповільнюють його розвиток, та визначено шляхи їх подолання.

Ключові слова: регіон, малі підприємства, фізичні особи - підприємиі, обсяги реалізованої продукuіiі, прибуток.

Статья посвящена исследованию малого предпринимательства в Днепропетровской области в сравнении с показателями по Украине в целом. Дана характеристика деятельности субъектов хозяйствования в Украине и Днепропетровской области с 2013 по 2017 г. по показателям количества предприятий, количества занятых работников и объемам реализованной продукции с выделением деятельности малых предприятий и оценкой их доли в общей структуре. Определено, что в Днепропетровской области мальій бизнес выполняет сочиальную функцию, а именно обеспечивает больщую часть населения рабочими местами. Рассмотрена характеристика физических лии - предпринимателей по основным показателям их деятельности. Обозначены проблемы малого предпринимательства, которые замедляют его развитие, и определены пути их преодоления.

Ключевые слова: регион, малые предприятия, физические лица - предприниматели, объемы реализованной продукции, прибыль.

The relevance of the study shows the importance of small business development for any country in the world. Precisely small business is one of the important conditions of economic growth in the country and an important factor of optimization of markets, especially in the system of market relations. And further development of small business requires in-depth study of the formation factors, the territorial features of the region, the formation and implementation of an appropriate effective regional policy. The author gave analysis of small business and identified the main problems of its development. The article described the characteristics of business entities activity in Ukraine and in Dnipropetrovsk region from 2013 to 2017 with next indexes: the number of enterprises, the number of employees and the sales volume with the allocation of small businesses and the assessment of their share in the overall structure. The author has analyzed the number of employed workers at small enterprises and found out that it is lower in Dnipropetrovsk region than in Ukraine. But it has increased by 2 times more than overall Ukraine for the analyzed period. This means that small business implements a social function by providing more workplaces in Dnipropetrovsk region. The author reviewed the change of the sales volume not only in the national currency (hryvnia), but also in US dollars for most complete analysis. The analysis shows 
that the sales volume in national currency increased, but in terms of the US dollar, it decreased contrary. The performed analysis of private entrepreneur activity is very important. Exactly private entrepreneurs form a small business. There is one of the negative facts: a significant number of registered small enterprises are not operating, but most of operating ones are engaged in fast profitable business activities, such as trade and brokerage service. The author noted that the creation of clusters and technology parks will be more effective way to connect small businesses with large enterprises in the industrial regions of Ukraine. Small business can be a supplier of innovative technologies for large enterprises.

Keywords: region, small enterprises, individual entrepreneurs, sales volumes, profit.

Постановка проблеми. Мале підприємництво виступає структурним елементом ринкової економіки будь-якої країни. Розвиток малого бізнесу вважається однією із важливих умов економічного росту в країні та важливим чинником оптимізації ринків, особливо в системі ринкових відносин. Як зазначає С.I. Павлова, саме цей сектор економіки відігравав роль необхідної передумови створення ринкового середовища [1]. Малий бізнес виконує значну роль у розвитку економіки регіону та вирішенні низки проблем на місцевому рівні, а саме розвитку конкуренції між продавцями продукції, забезпечення робочими місцями працездатного населення, підвищення рівня життя та поліпшення соціального середовища. Сьогодні створення сприятливих умов в Україні для розвитку малого підприємництва є проблемою. Подальший розвиток малого підприємництва потребує глибокого дослідження чинників, які його утворюють, територіальних особливостей регіону, формування та реалізації відповідної ефективної регіональної політики.

Аналіз останніх досліджень і публікацій. Після проголошення незалежності України розпочався етап становлення правового законодавства для ведення підприємницької діяльності та посилився інтерес вітчизняних учених до дослідження функціонування малого підприємництва як одного 3 чинників формування доходів домогосподарств. І.Д. Падерін [2] приділяє значну частину уваги малому бізнесу в розрізі регіонів та зазначає, що мале підприємництвоце базадля значних соціальних зсувів у суспільстві та його стабільності у вигляді так званого середнього класу. А.В. Попський [3] виявив фінансові важелі розвитку малого бізнесу. Л.Г. Безчасний [4] ставив за основу роз- витку підприємництва вирішення питань інвестиційної привабливості. Незважаючи на значну кількість досліджень у цій сфері, проблеми створення, розвитку та функціонування малого підприємництва недостатньо вивчені.

Мета статті полягає в аналізі малого підприємництва в Дніпропетровській області та висвітленні основних проблем у його розвитку.

Виклад основного матеріалу. Сектор малого бізнесу посідає ключове місце в економіці за кількістю, зайнятістю та обсягом реалізації. У 2017 р. в Україні понад 95,5\% становили суб'єкти малого підприємництва, суб'єкти великого бізнесу - 0,1\%, а середнього $-4,4 \%$ [5].

Дніпропетровська область - друга за територією після Одеської, займає 5,3\% площі території України та 7,6\% чисельності населення. За даними Державної служби статистики, вона виробляє 244278 млн. грн. (у 2016 р.) продукції, що становить майже $10,3 \%$ валового внутрішнього продукту (2 385367 млн. грн. у 2016 р.) [5].

У Господарському кодексі України зазначено, що суб'єкти малого підприємництва включають у себе суб'єктів мікропідприємництва, які становлять його більшу частку. В Україні до малого підприємництва належать підприємства, у яких річний розмір доходу суб'єкта господарювання не перевищує суму, еквівалентну 10 млн. євро (визначену за середньорічним курсом Національного банку України), та чисельність працівників не перевищує 50 осіб [6]. Фізичні особи - підприємці не можуть бути суб'єктами великого підприємництва. Кількість підприємств в Україні та Дніпропетровській області наведено на рис. 1 та 2. 


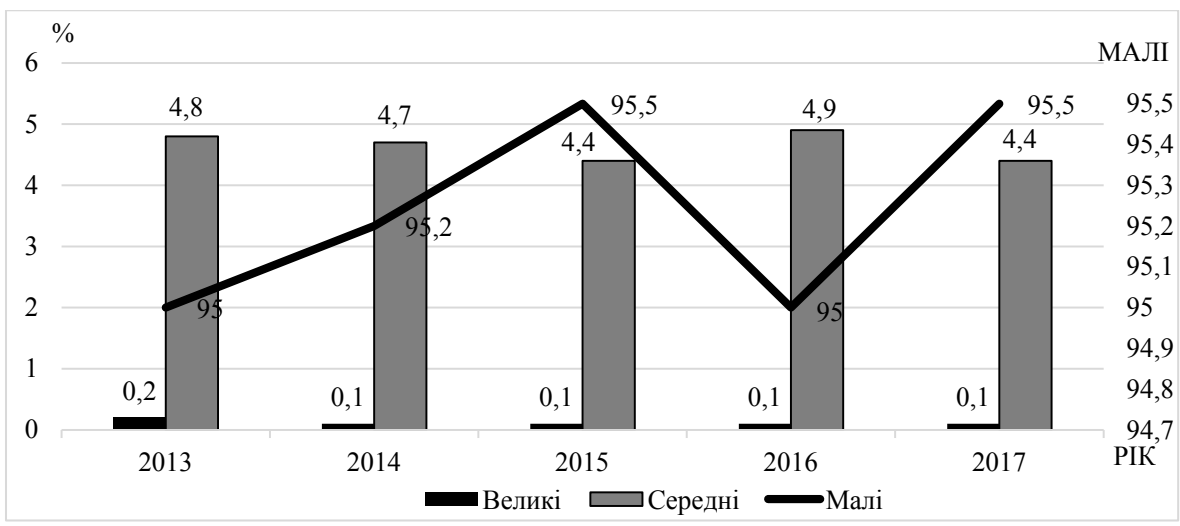

Рис. 1. Кількість підприємств за розміром в Україні в період 2013-2017 рр.

В Україні за період 2013-2017 рр. за кількістю підприємств спостерігалася негативна тенденція до зменшення (рис. 1). Так, у 2013 р. кількість великих підприємств становила 659 од., а в 2017 р. зменшилась на 260 од. Кількість середніх підприємств у 2013 р. становила 18859 од., а в 2017 р. зменшилася на 3925 од. Проте кількість малих підприємств у загальній структурі збільшилася на $0,5 \%$, незважаючи на те що в натуральних показниках їх кількість зменшувалася (у 2013 р. вона становила 373809 од., а в 2017 р. зменшилася на 40888 од.). У Дніпропетровській області в період 2013-2017 рр. за кількістю підприємств спостерігалася негативна тенденція до зменшення (рис. 2).
Так, у 2013 р. кількість великих підприємств становила 67 од., а в 2017 р. зменшилася на 19 од. Кількість середніх підприємств у 2013 р. становила 1476 од., а в 2017 р. зменшилася на 235 од. Кількість малих підприємств у 2013 р. становила 26651 од., в 2017 р. зменшилася на 48 од. У загальній структурі кількість великих підприємств за аналізований період зменшилася на $0,1 \%$, середніх - на $0,8 \%$. Проте кількість малих підприємств збільшилася на $0,9 \%$, незважаючи на те що в натуральних показниках їх кількість зменшувалася.

Отже, показник, який характеризує кількість малих підприємств, приблизно однаковий. По Україні він становить 95,5\%, а в Дніпропетровській області - 95,4\%. Але

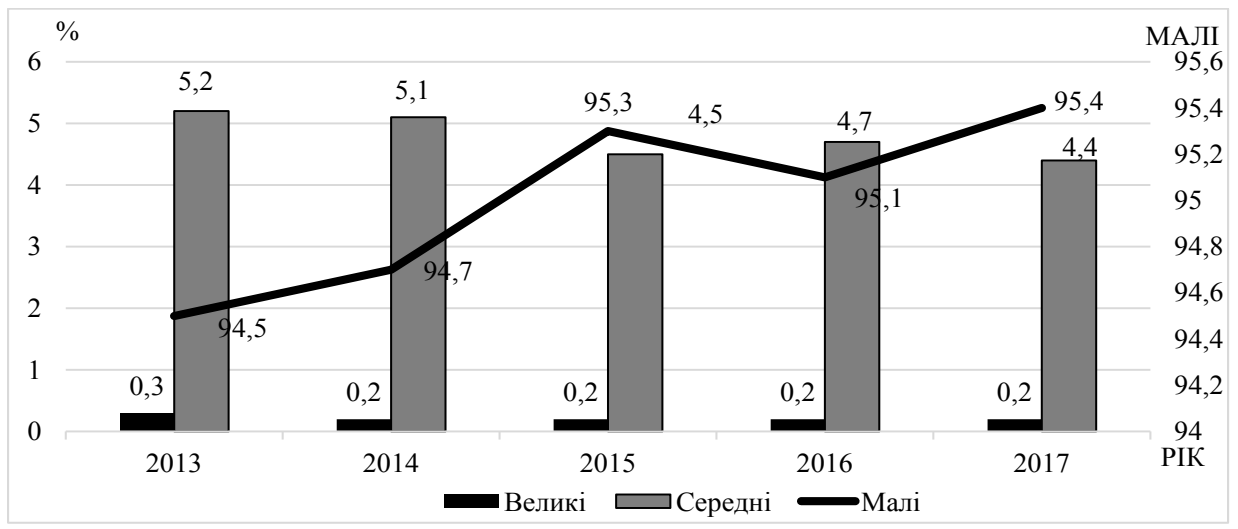

Рис. 2. Кількість підприємств у Дніпропетровській області за розміром у період 2013-2017 pp. 


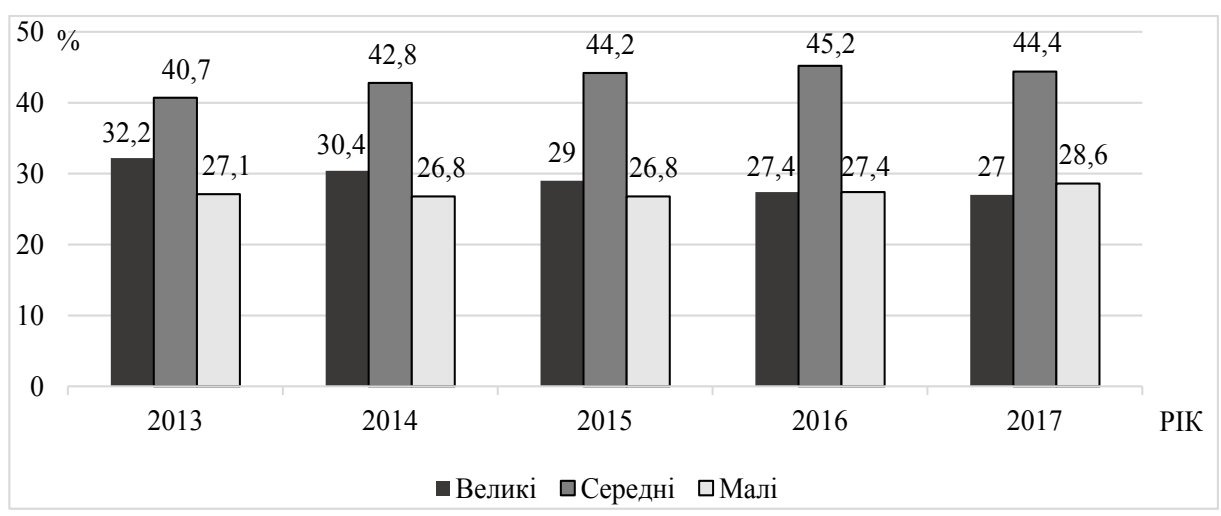

Рис. 3. Кількість зайнятих працівників на підприсмствах України в період 2013-2017 pp.

збільшення за період 2013-2017 рр. по Україні відбулося на 0,5\%, а в Дніпропетровській області - на $0,9 \%$, що говорить про значний потенціал регіону.

В Україні та Дніпропетровській області, відповідно до зменшення кількості підприємств, чисельність зайнятих працівників також демонструє тенденцію до зменшення (рис. 3 та 4).

В Україні в 2013 р. кількість зайнятих працівників на великих підприємствах становила 2 383,7 тис. осіб, а в 2017 р. зменшилася на 825,1 тис. осіб. Кількість зайнятих працівників на середніх підприємствах у 2013 р. становила 3 012,1 тис. осіб, а в 2017 р. зменшилася на 450,3 тис. осіб. Чисельність працюючих на малих підприємствах у 2013 р. становила 2 010,7 тис. осіб, у 2017 р. зменшилася на 359,7 тис. осіб. У загальній структурі кількість зайнятих працівників на великих підприємствах України за аналізований період зменшилася на $5,2 \%$. У зв'язку із цим на середніх та малих підприємствах відбулося збільшення їхньої ваги у загальній структурі на 3,7\% та 1,5\% відповідно. Кількість зайнятих на середніх та малих підприємствах збільшилася, незважаючи на те що в натуральних показниках їх кількість мала тенденцію до зменшення.

На великих підприємствах Дніпропетровської області кількість зайнятих працівників

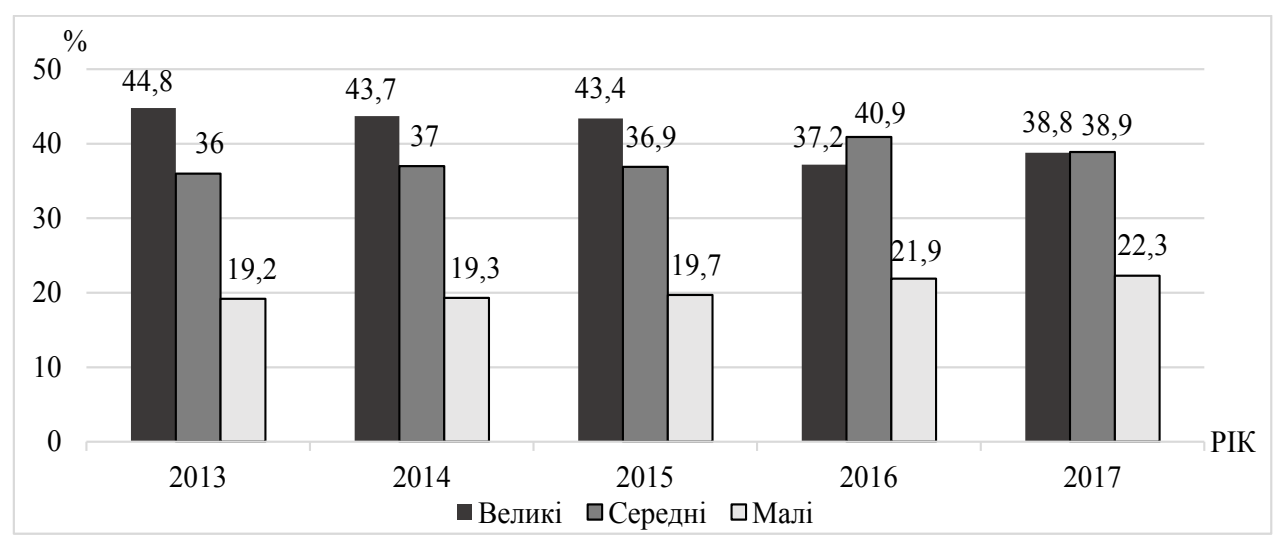

Рис. 4. Кількість зайнятих працівників на підприємствах Дніпропетровської області в період 2013-2017 рp. 
порівняно 3 іншими регіонами України досить значна - 233407 осіб [7]. На середніх підприємствах кількість зайнятих працівників - 234,6 тис. осіб, а на малих підприємствах - 134,2 тис. осіб. Відповідно до зменшення кількості підприємств чисельність зайнятих працівників також демонструє тенденцію до зменшення (рис. 4).

Так, у 2013 р. кількість зайнятих працівників на великих підприємствах становила 331,5 тис. осіб, а в 2017 р. зменшилася на 98,1 тис. осіб. Кількість працюючих на середніх підприємствах у 2013 р. становила 266,3 тис. осіб, а в 2017 р. зменшилася на 31,7 тис. осіб. Чисельність працюючих на малих підприємствах у 2013 р. становила 142 тис. осіб, у 2017 р. зменшилася на 7,8 тис. осіб. У загальній структурі кількість зайнятих працівників на великих підприємствах Дніпропетровської області за аналізований період зменшилася на 6\%. У зв'язку із цим на середніх та малих підприємствах відбулося збільшення їх ваги у загальній структурі на
2,9\% та 3,1\% відповідно. Кількість зайнятих на середніх та малих підприємствах збільшилася, незважаючи на те що в натуральних показниках їх кількість мала тенденцію до зменшення.

Отже, показник кількості зайнятих працівників на малих підприємствах по Дніпропетровській області менший, ніж по Україні. По Україні цей показник становить 28,6\%, а по Дніпропетровській області - 22,3\%. Збільшення за період 2013-2017 рр. по Україні відбулося на $1,5 \%$, а по Дніпропетровській області - на 3,1\%. Це означає, що в Дніпропетровській області малий бізнес виконує соціальну функцію, тобто забезпечує більшу кількість населення робочими місцями.

Розглянемо зміну обсягу реалізованої продукції в національній валюті (гривні) та в доларах США. Структура обсягу реалізованої продукції на підприємствах у національній валюті та доларах США буде однаковою (рис. 5). Відмінність буде лише в грошових показниках за рахунок зміни курсу валют. Дані курсу валюти наведено в табл. 1 .

\section{Таблиця 1}

Офіційний курс гривні до долару США за 2013-2017 рр.

\begin{tabular}{|c|c|c|c|c|c|c|c|}
\hline рік & $\mathbf{2 0 1 2}$ & $\mathbf{2 0 1 3}$ & $\mathbf{2 0 1 4}$ & $\mathbf{2 0 1 5}$ & $\mathbf{2 0 1 6}$ & $\mathbf{2 0 1 7}$ & $\begin{array}{c}\text { Приріст } \\
\mathbf{2 0 1 7 / 2 0 1 3}\end{array}$ \\
\hline грн. & 8,2769 & 7,993 & 11,8867 & 21,8447 & 25,5513 & 26,5966 & $+18,6036$ \\
\hline
\end{tabular}

Джерело: розроблено автором на основі [8]

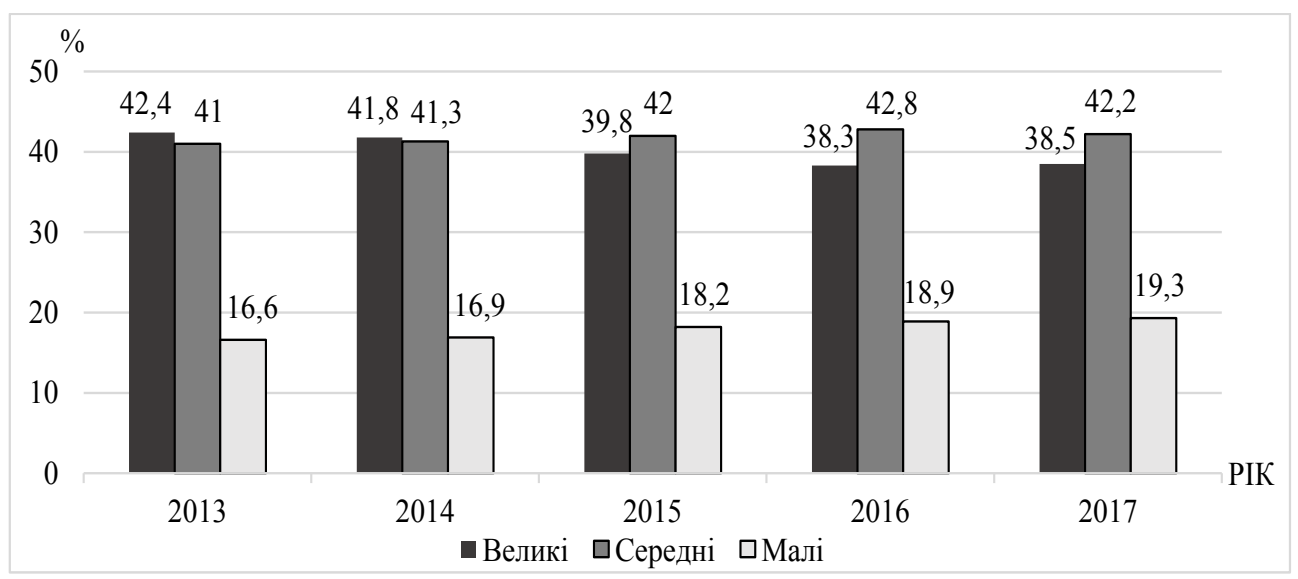

Рис. 5. Структура обсягу реалізованої продукції на підприсмствах України 3a 2013-2017 pp. 
У загальній структурі обсяг реалізованої продукції великими підприємствами за аналізований період зменшився на 3,9\%. Це пов'язано зі скороченням кількості великих підприємств та збільшенням чисельності підприємств іншого розміру. У зв'язку із цим на середніх та малих підприємствах відбулося збільшення частки реалізованої продукції у загальній структурі на 1,2\% та 2,7\% відповідно.

У 2017 р. обсяг реалізації великими підприємствами становив 2923381 млн. грн., середніми - 3198146 млн. грн. та на малими 1463334 млн. грн. Напідприємствах усіх розмірів у національній валюті спостерігається тенденція до збільшення обсягів реалізації (рис. 6). У 2017 р. обсяг реалізованої продукції на великих підприємствах зріс на 1205990 млн. грн. порівняно з 2013 р. (1 717391 млн. грн.), на середніх - на 1535581 млн. грн. (у 2013 р. 1662565 млн. грн.) та на малих підприємствахна 793075 млн.грн.(у2013р.-670259млн.грн.).

Якщо розглядати динаміку обсягу реалізованої продукції в доларах США, бачимо іншу тенденцію. У 2017 р. обсягреалізації великими підприємствами становив 109915 млн. дол., середніми - 120246 млн. дол. та на малими 55020 млн. дол.

На підприємствах усіх розмірів спостерігається тенденція до зменшення обсягів реа- лізації продукції. На великих підприємствах у 2017 р. обсяг реалізованої продукції зменшився на 104946 млн. дол., або на 48,8\%, порівняно з 2013 р. (214 861 млн. дол.), на середніх - на 87756 млн. дол., або на 42,2\% (у 2013 р. - 208003 млн. дол.), та на малих підприємствах - на 28836 млн. дол., або на $34,4 \%$ (у 2013 р. - 83856 млн. дол.). Варто зазначити, що в період 2013-2015 рр. обсяг реалізації в доларах знижувався, проте вже в 2016 р. почав збільшуватися.

Згідно зі статистичними даними, на території Дніпропетровської області станом на кінець 2016 р. зареєстровано 24325 суб'єктів малого підприємництва, 3 них 82,8\% фізичні особи - підприємці [9]. При цьому кількість суб'єктів господарювання в Дніпропетровської області становить лише 8,4\% від загальнодержавного рівня, що пояснюється значною кількістю промислових підприємств у регіоні.

У 2017 р. обсяг реалізації великими підприємствами становив 510565 млн. грн., середніми - 230484 млн. грн. та на малими 128322 млн. грн. На підприємствах усіх розмірів у національній валюті спостерігається тенденція до збільшення обсягів реалізації (рис. 7). У 2017 р. обсяг реалізованої продукції на великих підприємствах

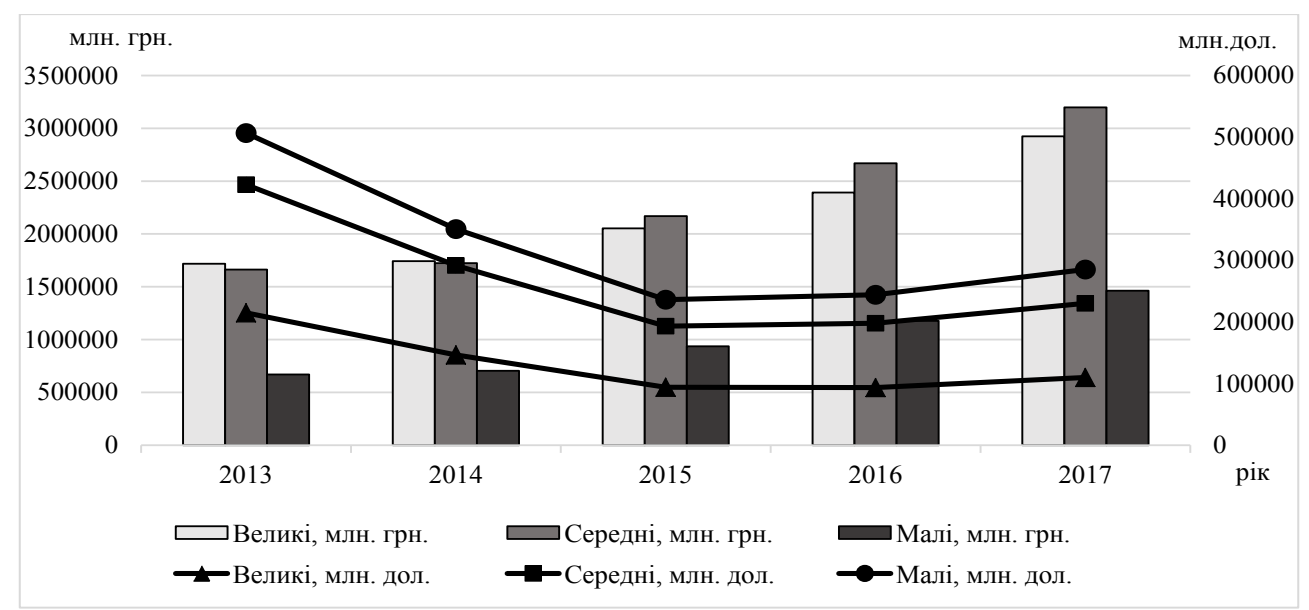

Рис. 6. Обсяг реалізованої продукції на підприсмствах України в гривнях та доларах США за 2013-2017 pp. 


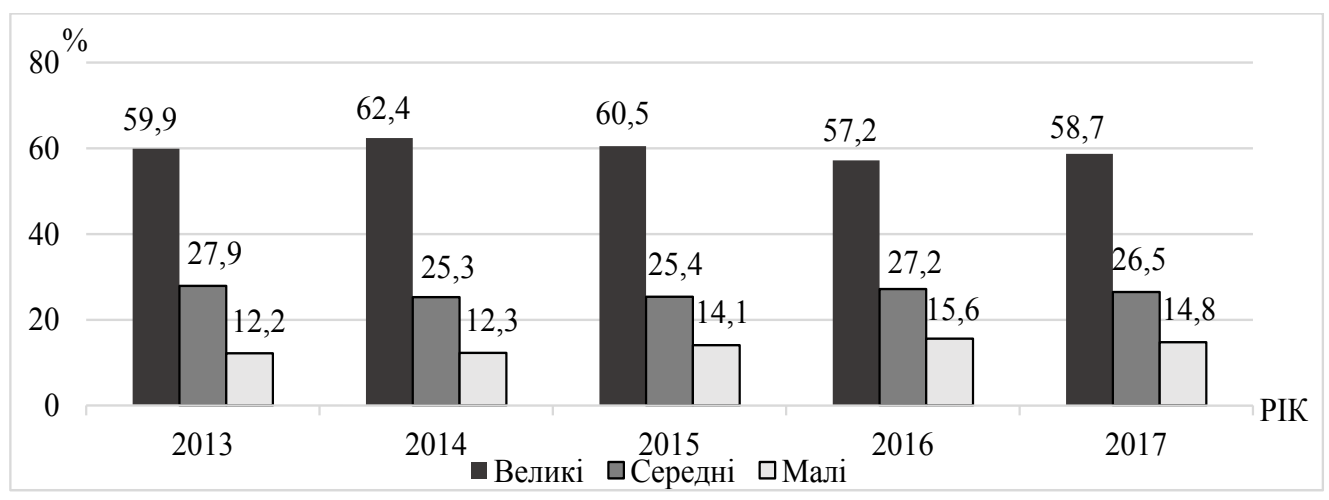

Рис. 7. Обсяг реалізованої продукції на підприємствах Дніпропетровської області 3a 2013-2017 pp.

зріс на 244136 млн. грн. порівняно 3 2013 р. (266 429 млн. грн.), на середніх - на 106583 млн.грн. (у2013 р.-123901 млн.грн.)та на малих підприємствах - на 74 102,5 млн. грн. (у 2013 р. - 54 219,5 млн. грн.).

У загальній структурі обсяг реалізованої продукції великими підприємствами за аналізований період зменшився на 1,2\%. Це пов'язано зі скороченням кількості великих підприємств та збільшенням чисельності підприємств іншого розміру. У зв'язку із цим на малих підприємствах відбулося збільшення частки реалізованої продукції у загальній структурі на 2,6\%.

Якщо розглядати динаміку обсягу реалізованої продукції в доларах США, бачимо іншу тенденцію (рис. 8). У 2017 р. обсяг реалізації великими підприємствами становив 19197 млн. дол., середніми - 8666 млн. дол. та малими - 4825 млн. дол.

На підприємствах усіх розмірів спостерігається тенденція до зменшення обсягів

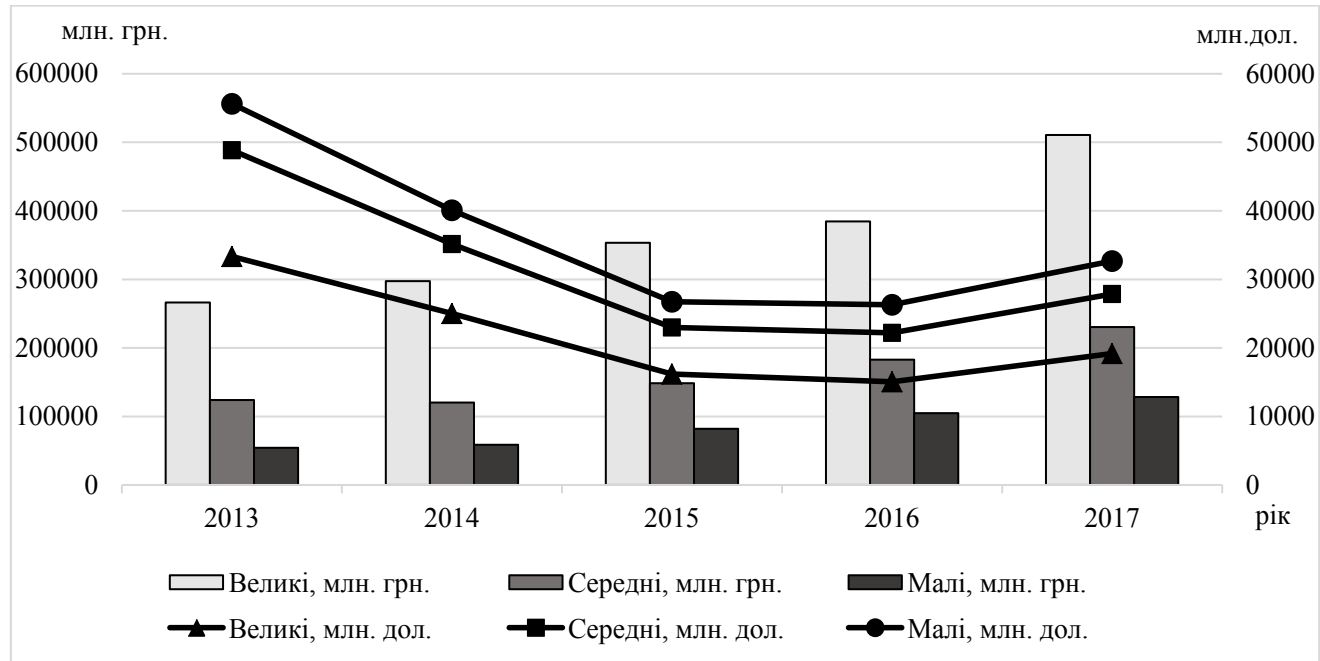

Рис. 8. Обсяг реалізованої продукції на підприсмствах Дніпропетровської області в гривнях та доларах США за 2013-2017 pp. 


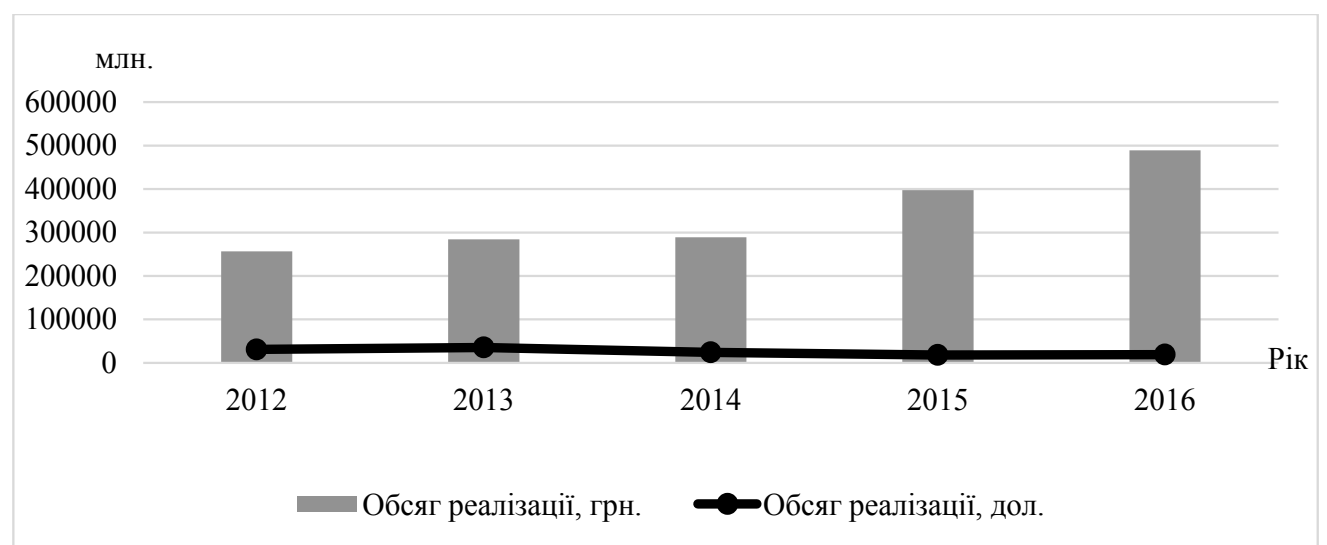

Рис. 9. Обсяг реалізованої продукції фізичними особами - підприємцями (ФОП) в Україні

реалізації продукції. На великих підприємствах у 2017 р. обсяг реалізованої продукції зменшився на 14136 млн. дол., або на 42,4\%, порівняно з 2013 р. (33 333 млн. дол.), на середніх - на 6835 млн. дол., або на 44,1\% (у 2013 р. - 15501 млн. дол.), та на малих підприємствах - на 1959 млн. дол., або на 28,9\% (у 2013 р. - 6783 млн. дол.). Варто зазначити, що в період 2013-2015 рр. обсяг реалізації в доларах знижувався, проте вже в 2016 р. почав збільшуватися.

Отже, показник обсягу реалізованої продукції на малих підприємствах по Дніпропетровській області менший, ніж по Україні. По Україні цей показник становить 19,3\%, а по Дніпропетровській області - 14,8\%. Збільшення за період 2013-2017 рр. по Україні відбулося на 2,7\%, а по Дніпропетровській області - на 2,6\%. Проте під час розгляду зміни обсягу реалізованої продукції в доларах США спостерігаємо її зменшення, а саме по Україні - на $34,4 \%$, а по Дніпропетровській області - на 28,9\%.

Варто зазначити, що в період 2012-2016 pp. кількість зареєстрованих фізичних осіб - підприємців збільшилася на 265403 од. Складна політична та економічна ситуація в Україні в 2014 р. та, як наслідок, підвищення рівня безробіття спонукали людей самостійно займатися підприємницькою діяльністю. Тільки протягом 2014 р. зареєстровано більше 262 тис. нових фізичних осіб - підприємців та незначне збільшення їх кількості протягом 2015 р. Проте в 2016 р. їх кількість зменшилася на 71717 од. порівняно з 2015 р. На жаль, офіційні дані про діяльність фізичних осіб - підприємців протягом 2017 р. ще не оприлюднено.

За аналізований період також відбувається і збільшення кількості зайнятих працівників, що наймають фізичні особи - підприємці, та обсягів реалізованої продукції (рис. 9). У період 2012-2014 рр. кількість зайнятих працівників постійно зростала, проте в 2015 р. скоротилася на 207,9 тис. осіб. Приріст зайнятих працівників за 2012-2016 рр. становив 29,3 тис. осіб.

Обсяг реалізованої продукції фізичними особами - підприємцями за аналізований період збільшився на 232555 млн. грн. Потрібно зауважити, що на збільшення обсягу реалізації вплинуло не тільки поліпшення економічного становища, а й ріст курсу долара США. У 2012 р. його середньорічний курс становив 7,991 грн., а в 2016 р. - 25,551 грн. Відповідно, у доларах обсяг реалізованої продукції фізичними особами - підприємцями в 2012 р. становив 32 117,28 млн. дол., а в 2016 р. - 19 146,2 млн. дол., тобто фактично відбувається зменшення обсягів на 12 971,08 млн. дол.

На території Дніпропетровської області станом на кінець 2016 р. зареєстровано 
125841 фізична особа - підприємець. За аналізований період 2012-2016 рр. їх кількість постійно збільшувалася та зросла на 43470 осіб. Найбільша кількість зайнятих працівників у фізичних осіб - підприємців була зареєстрована в 2014 р. та становила 211,4 тис. осіб, проте в 2015 та 2016 рр. вона почала зменшуватися. Незважаючи на це, приріст за 2012-2016 рр. становив 31,7 тис. осіб.

Обсяг реалізованої фізичними особами підприємцями продукції на території Дніпропетровської області протягом аналізованого періоду постійно зростав (рис. 10) та в 2016 р. становив 40 233,5 млн. грн., тобто збільшився на 21 981,6 грн. порівняно з 2012 р. Відповідно, в доларах обсяг реалізованої продукції фізичними особами - підприємцями в 2012 р. становив 2 205,16 млн. дол., а в 2016 р. - 1574,63 млн. дол. Фактично відбувається зменшення обсягів на 630,54 млн. дол.

Отже, за аналізований період 2013-2017 рр. кількість ФОП в Україні збільшилася на $6,4 \%$, у Дніпропетровській області цей показник збільшився на 8,4\%. Чисельність працюючих у фізичних осіб - підприємців в Україні збільшилася на 5,6\%, а в Дніпропетровській області - на 7,2\%. Частка обсягу реалізованої продукції у національній валюті в Україні зросла на 1,5\%, а в Дніпропетровській області - на 1,7\%. Проте під час розгляду зміни обсягу реалізованої продукції в доларах США спостерігаємо іiі зменшення, а саме по Україні на 38,3\%, а по Дніпропетровській області - на 28,6\%.

Якщо розглядати всі регіони Україні за показником розвитку малого бізнесу, Дніпропетровська область знаходиться на передостанньому місці. За даними Державної служби статистики, у 2017 р. обсяг реалізованої продукції становив лише 19,2\% від загального обсягу по всіх малих підприємствах. У 2013 р. цей показник становив $16,9 \%$, тобто відбулося збільшення на 2,6\%. Наявною проблемою є те, що мале підприємництво не розвивається в промислових регіонах країни. Розвиток відбувається лише в західних регіонах. Так, у Дніпропетровській області частка обсягу реалізованої продукції малими підприємствами в 2013 р. становила $12,2 \%$, а в 2017 р. $-14,4 \%$, тобто збільшилася на 2,6\%. У Тернопільській області частка обсягу реалізованої продукції малими підприємствами у 2013 р. становила 13,0\%, а в 2017 р. $-32,0 \%$, тобто збільшилася на $19 \%$.

Особливо негативним явищем стало те, що значна кількість зареєстрованих малих підприємств не діє, а більша частина діючих займається такими швидкоприбутковими видами господарської діяльності, як торгівля та посередницькі послуги. Це пояснюється тим, що суб'єкти малого підприємництва розвиваються в умовах несприятливого інвестиційного клімату, що робить невигідними довгострокові виробничі вкладення.

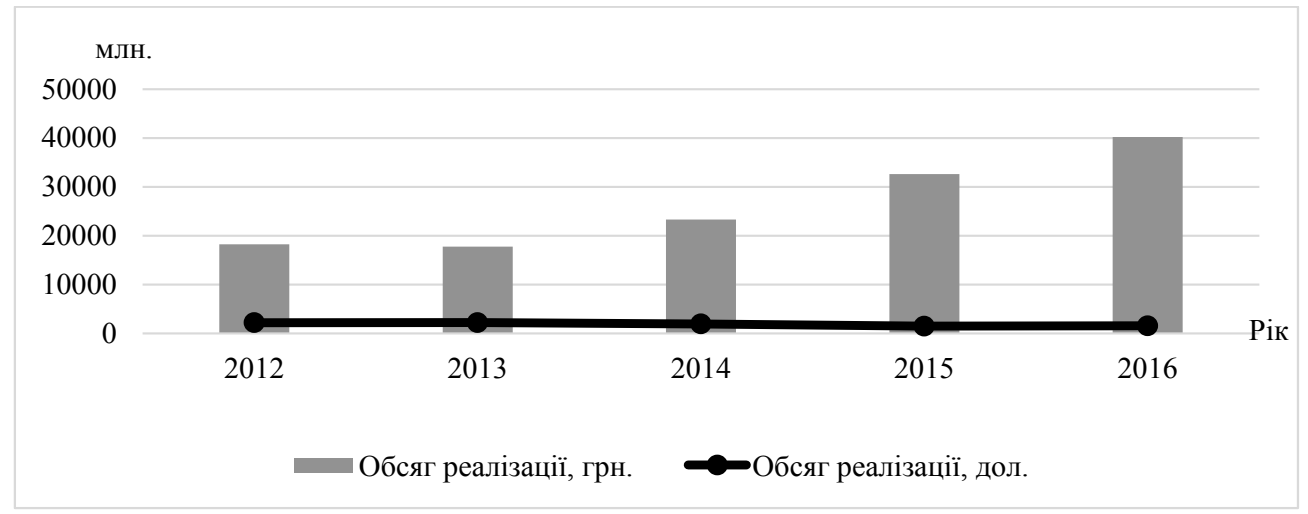

Рис. 10. Обсяг реалізованої продукції фізичними особами - підприємцями (ФОП) у Дніпропетровській області 
У промислових регіонах Україні більш ефективним буде створення кластерів та технопарків для зв'язку малого бізнесу з великими підприємствами. Малий бізнес може виступати постачальником інноваційних технологій для більших підприємств. Тому така робота вигідно відобразиться на ефективності підприємств усіх видів.

До основних проблем, які треба вирішувати для розвитку малого бізнесу в Україні та Дніпропетровській області, можна віднести:

- недостатнє нормативно-правове регулювання підприємницької діяльності, а іноді його відсутність;

- відсутність та обмеженість для малих підприємств інвестиційної та фінансово-кредитної підтримки;

- відсутність дієвого політичного механізму щодо малого підприємництва;

- несформовану інфраструктуру підтримки підприємців.

Отже, мале підприємництво забезпечує створення нових робочих місць, зайнятість працездатного населення та скорочення кількості соціально незахищеного населення. Також мале підприємництво надає можливість відкрити свій бізнес у виробничій, науковій або іншій діяльності, реалізуючи в ній свої здібності та отримуючи стабільні доходи. Крім того, даний вид підприємств сприяє зниженню рівня бідності та забезпечує соціальну стабільність регіону. Малі підприємства мають поглиблену спеціалізацію, швидше реагують на зміни попиту та пропозиції, ніж великі підприємства, тому частіше розробляють нові товари. За умов вузької спеціалізації й використання новітньої техніки вони виступають як дієвий конкурент великих корпорацій.

Висновки. Сьогодні в Україні $€$ багато проблем, які перешкоджають розвитку підприємництва, вирішення яких забезпечить підвищення ефективності підприємницької діяльності, розширення підприємницького сектору та зменшення тіньового сектору. Основну роль у цих перетвореннях має відігравати держава.

Мале підприємництво не розвивається в промислових регіонах країни. Так, у Дніпропетровській області частка обсягу реалізованої продукції малими підприємствами у 2013 р. становила $12,2 \%$, а в 2017 р. - 14,4\%, тобто збільшилася на 2,6\%. У Тернопільській області частка обсягу реалізованої продукції малими підприємствами у 2013 р. становила 13,0\%, а в 2017 p. - 32,0\%, тобто збільшилася на 19\%.

Мале підприємництво $\epsilon$ важливим засобом вирішення регіональних соціально-економічних проблем: структурної перебудови економіки, наповнення ринку товарами та послугами, створення конкурентного середовища, створення нових робочих місць шляхом самозайнятості, наповнення місцевих бюджетів тощо.

В умовах системних структурних перетворень національної економіки сектор малого підприємництва виконує провідну роль у підвищенні рівня життя громадян. Малий бізнес має призвести до насичення ринку товарами та послугами, підвищити експортний потенціал регіону, тому тема роботи актуальна та потребує подальших досліджень.

\section{Список використаних джерел:}

1. Павлова С.I. Регіональний статистико-економічний аналіз розвитку малого та середнього підприємництва в Житомирській області. Вісник Житомирського державного технологічного університету. Серія «Економіка, управління та адміністрування». 2017. № 3. С. 54-60.

2. Редина Н.И., Падерин И.Д. Методы и опыты исследований развития малого предпринимательства промышленного региона. Вісник економічної науки Украӥни. 2011. № 1. С. 128-132.

3. Попський А.В. Організаційно-правові засади становлення та функціонування малого й середнього бізнесу. Теорія та практика державного управління. 2015. № 4. С. 77-82.

4. Безчасний Л.К. Формування інноваційної моделі економічного зростання в Україні. URL : http://www.nam.kiev.ua/ape/n_02_7/bezchasnyi.html.

5. Показники структурної статистики по суб'єктах господарювання з розподілом за їх розмірами. Державна служба статистики України. 2018. URL : http://www.ukrstat.gov.ua/. 
6. Господарський кодекс України : Закон України № 436-IV від 16.01.2003. URL : http://zakon.rada.gov.ua/cgi-bin/laws/main.cgi?nreg=436-15 (дата звернення: 21.02.2019).

7. Кількість підприємств за видами економічної діяльності з розподілом на великі, середні, малі та мікропідприємства. Головне управління статистики у Дніпропетровській області. 2018. URL : http://www.dneprstat.gov.ua.

8. Курс гривні щодо іноземних валют. Офіиійне Інтернет-представництво Національного банку України. 2018. URL : https://bank.gov.ua/control/uk/index.

9. Вернер I.Є. Статистичний щорічник України за 2016 рік. Київ, 2017. 611 с. 